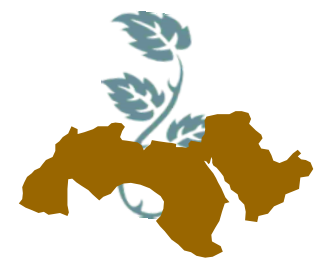

\title{
RESPONSE OF COTTON YIELD AND LINT PROPERTIES TO MINERAL N.P.K NANO-FERTILIZATION
}

\author{
Zakzok $^{2}$, A.K.; R.Th. Abdrabou'; Abeer S. Arafa ${ }^{2}$ and \\ G.A.A. Abd-Elsamad ${ }^{1}$ \\ 1- Agronomy Dept., Fac. of Agric., Ain Shams Univ., Cairo, Egypt \\ 2- Cotton Research Institute, Agric. Research Center, Giza, Egypt
}

Keywords: Cotton, Fertilizer, Bio-organic, Nano, Fiber and chitosan

\section{ABSTRACT}

Two field experiments were conducted at Sakha Research Station, Cotton Research Institute, Agricultural Research Center at Giza, Egypt during the two summer growing seasons 2014 and 2015 The aim of the work was to study the effect of the combination among nano-fertilization ,mineral fertilization and organic fertilization on growth, yield and fiber technological properties of Egyptian cotton Giza 94 cultivar.

The most important results can be summarized as follows: Response of cotton yield and lint properties to mineral N.P.K nano-fertilization the complex treatment contains half dose of both the nanofertilizer and the bio-organic fertilizer gave the highest reading for plant height $(\mathrm{cm})$, number of fruiting branches per plant, number of open bolls per plant, boll weight (gram), lint percentage, Seed index, Seed cotton yield (Kentar/fed.), Lint cotton yield (Kentar/fed.), fiber maturity ratio (MR), upper half mean (UHM)mm, fiber uniformity index (UI), fiber strength ( $g /$ tex), and micronaire value flowed by the treatment $100 \%$ nano then the recommended dose of mineral fertilizer NPK. On the other hand, the lowest values for all the above traits, were recorded from the half does of NPK mineral fertilizer in 2014 and 2015 seasons, .While, There were no significant differences between the means of the fiber elongation \% due to the treatments applied during the study in 2014 season .It's worthy to mention that, the percentage of fiber elongation had no constant trend due to fertilizer transactions applied on the adopted genotype during 2015 season, meaning that nano-fertilizer is boosting the fiber elongation percent.

\section{INTRODUCTION}

Nowadays cotton faces many problems causes retreating of its planting area year after year. One of the reasons make cotton lost its sustainability in Egypt is the increase in production costs. Fertilization and harvesting exhibits the highest production cost. After building the high dam the Egyptian soil lost its fertility, farmers compensate this decrement by adding high mineral fertilization rates. In fact, mineral fertilizer disadvantages are high. They contaminate the soil, underground water which reflected badly on the living organism and human health, cotton yield and technological properties.

Cotton agronomist tries to solve these problems by using organic fertilizers and bio-organic fertilizers. Use of organic fertilizer improves physical properties of the soil which reflected positively on increasing and quantity. (Sasson et al 2007) mixed bacteria strains (PGPR) and organic matter to increase the soil content of $\mathrm{N}, \mathrm{P}, \mathrm{K}$ elements along with soil total fungi, bacteria actinomycetes counts, as well as, boll weight (gram), lint percentage, seed index and seed cotton yield (Kentar/fed.), and fiber physical properties. Also, biofertilizer is a natural and sustainable nutritional input. Mainly there are three types of bio-fertilizers which are used on mass scale. These are nitrogenous phosphoric, and potash bio-fertilizer. The use of Azotobacter enhances recently, cotton yield depending on variety and strain efficiency, (Shivalingaiah 2007 and Eichert et al 2008)

Recently, nanotechnology has extended its relevance in agriculture to improve fertilizer formulations for increase uptake in plant cells and minimizing nutrient loss. The great surface area and small size of the nano-materials could lead to enhance the uptake efficiency of nutrients for crop (DeRosa et al 2010). 
Nano-fertilizers improve the uptake of root pores, or it could be facilitated by complication with molecular transporters or root, through the formation of new pores, or by exploitation of endocytosis or ion channels. (Dhale et al 2011). Leaf also containing nano- and micro structured surfaces, called cuticle pores and stomata. A study on the penetration of two different sizes of watersuspended particles (43 $\mathrm{nm}$ or $1.1 \mu \mathrm{m}$ diameter) into leaves indicated that the nano-sized particles may enter the leaf through the stomatal pores (Riko et al 2011) A second study looking at pore diameters in a series of plant leaves found nanosized pores in both stomatous and a stomatous leaf surfaces, although diameters varied widely. Also nano-fertilizers are characterized by slow or controlled release mechanisms. They could precisely release their active ingredients in responding to environmental triggers and biological demands. These attributes of nanoparticles are due to their high surface area to volume ratio, high solubility, and specific targeting due to small size, high mobility, and low toxicity (Arafa and Abd El-All 2013).In general, Nano-scale fertilizer considered an innovative topic should be studied carefully to be aware by its influences on soil, environmental characters, crop growth, yield and quality.

\section{MATERIALS AND METHODS}

Two field experiments were conducted at Sakha Research Station, Cotton Research Institute, Egypt during the two summer growing seasons, 2014 and 2015. The aim of present study was to study the effect of the combination among nano-fertilization, mineral fertilization and organic fertilization on growth, seed yield, lint yield, and fiber technological properties of Egyptian cotton.

The study included eight treatments $(100 \%$ mineral fertilizer NPK as recommended dose, $50 \%$ mineral fertilizer NPK, 50\% Organic fertilizer $+50 \%$ Nano NPK, $50 \%$ mineral fertilizer NPK $+50 \%$ Organic fertilizer, $50 \%$ mineral fertilizer NPK $+50 \%$ Nano NPK, 100\% Nano NPK, 100\% Organic fertilizer, and $50 \%$ Nano NPK)

The recommended fertilization dose for cotton (60kg N/feddan, $45 \mathrm{~kg} \mathrm{~K}_{2} \mathrm{O} /$ feddan, and $22 \mathrm{~kg}$ $\mathrm{P}_{2} \mathrm{O}_{5} /$ feddan) was applied as control. Nitrogen fertilizer was added as ammonium nitrate $(33.5 \% \mathrm{~N})$, phosphors as calcium super phosphate (15 $\% \mathrm{P}_{2} \mathrm{O}_{5}$ ) and potassium as potassium sulfate $\left(48 \% \mathrm{~K}_{2} \mathrm{O}\right)$.
The eight previous treatments were arranged in the complete randomized block design with four replicates, the plot size was $21.6 \mathrm{~m}^{2}$ (six ridges, $3.6 \mathrm{~m}$ as long and $0.6 \mathrm{~m}$ as ridge apart ).

Organic fertilizer was added as tea compost. The extract Compost mad from rice straw and cattle dunk which, had been composted in aerobic heap for three months, Tea compost extract was mixed with PGPR into ratios $1: 1$ to produce bioextracted tea compost.

The bio-fertilizer PGPR used in the study was a commercial multi-strains of Pseudomonas putida, Bacillus megatherium, Azospirillumbrasilense produced by culture collection of Agricultural Microbiology Department, Agricultural Research center at Giza, Egypt. PGPR concentration was adjusted to $1 \times 10^{8}$ (cfu/gr) for all treatments and at in the recommended times of cotton fertilization with $20 \mathrm{~L}$ /feddan. Nutrient contents of the extracted tea compost was (20 ppm ammonical nitrogen, $35 \mathrm{ppm}$ Nitrate nitrogen, 120 ppm Total nitrogen, 60 ppm Total Phosphorous , 50 ppm Total Potassium, 980 $\mathrm{mg} / \mathrm{l}$ COD chemical oxygen demand, 435 BOD Biochemical oxygen demand, $8.04 \mathrm{pH}$ ).

Nano-fertilizers concentration were 310ppm /L as nitrogen ,60ppm / $\mathrm{L}$ as phosphorus and 120 ppm / $L$ as potassium .Seeds of Egyptian cotton Giza 94 cultivar were sown on $10^{\text {th }}$ of April and $7^{\text {th }}$ of April in 2014 and 2015, respectively.

Physical and chemical analyses (Jackson 1976) of soil samples in 2014 and 2015 seasons are given in (Table, $\mathbf{1}$ ).

Table 1. Physical and chemical analysis of experimental soil in two seasons 2014 and 2015

\begin{tabular}{|l|l|l|l|}
\hline & & 2014 & 2015 \\
Mechanical analysis & Clay \% & 45.3 & 40.7 \\
& Silt \% & 31.3 & 39.6 \\
& Sand \% & 23.4 & 19.7 \\
\hline \multirow{3}{*}{ Chemical analysis } & PH & 8 & 7.79 \\
& EC & 3.5 & 4.22 \\
& SP \% & 70 & 70 \\
\hline \multirow{2}{*}{ Available macro } & $\mathrm{N}$ & 94.4 & 91.56 \\
Nutrients & $\mathrm{P}$ & 0.01 & 2.01 \\
(ppm) & $\mathrm{K}$ & 154.84 & 137.3 \\
\hline \multirow{3}{*}{ Solution lons (ppm) } & $\mathrm{Fe}$ & 1.95 & 4.1 \\
& $\mathrm{Zn}$ & 0.7 & 0.88 \\
& $\mathrm{Cu}$ & 5.13 & 0.04 \\
& & & \\
& &
\end{tabular}


At harvest ten plants were randomly collected from the inner ridges to determine the following attributes :(1- Plant height $(\mathrm{cm}), 2$ - Number of fruiting branches/plant, 3- Number of open bolls /plant, 4- Boll weight (gram.) ,5- lint percentage, (\%), 6- Seed index (100 seeds weight in gram.) for Seed cotton yield (Kentar/fed.) and Lint cotton yield (Kentar/fed.).

Fiber properties were estimated as micronaire value, fiber maturity ratio (MR), upper half mean (UHM)mm, fiber uniformity index (UI), fiber strength (g/tex), and fiber elongation percentage were determined using HVI instrument, all tested properties were done according to (ASTM: 1986). All properties were measured under standard conditions of $(65 \pm 2 \%)$ relative humidity and $\left(20 \pm 2 \mathrm{c}^{\circ}\right)$ room temp.

\section{Statistical analysis}

Obtained data were statistically analyzed according to (Snedecor and Cochran 1981).

\section{RESULTS AND DISCUSSION}

\section{1- Agronomic characteristics}

\subsection{Final plant height (cm)}

Data in (Table, 2) indicate that organic, mineral and nano-fertilization for Giza 94 had a significant effect on final plant height. These effects were appeared during the two growing seasons; 2014, 2015.

The obtained results indicated that the treatment contains half dose of both the nano-fertilizer and the bio-organic fertilizer gave the tallest plants (163.21 and $166.24 \mathrm{~cm}$ ) in 2014 and 2015 seasons, respectively followed by the recommended dose of NPK treatment than $100 \%$ nano. On the contrary, the transaction containing half recommended dose of mineral fertilizer NPK gave the shortest plants $(139.10$ and $143.00 \mathrm{~cm}$ ) in 2014 and 2015 seasons, respectively. These results may explained that, bio-organic able to augment the plants by interfering the concentration of known phytohormone that those bacteria one of the most important way affect the growth and development by producing Indole-3 acetic acid IAA that this hormone is led to plant shoot and root growth, development and subsequently increase uptake of nutrients by plant . Also, nano-fertilizer increased uptake in plant cells by minimizing nutrient loss and increase the nutrient use efficiency. These results are in agreement with (Morgan et al 2009 and Ghormade et al 2011), found that, nanoparticles fertilizers can result in modification of plant gene expression and associated biological pathways which ultimately affect plant growth, height and development.

\subsection{Number of fruiting branches (sympodia) per main stem}

Data illustrated in $($ Table, 2$)$ reveale that numbers of fruiting branches were affected significantly by fertilizer transactions. These results were fairly true in the two growing seasons; 2014 and 2015. The treatment of $50 \%$ nano-fertilizer $+50 \%$ bioorganic fertilizer gave the highest values of sympodia per plant (15.71 and 16.74), followed by $100 \%$ nano-fertilizer treatment as compared to the recommended dose of NPK mineral fertilizer in 2014 and 2015 seasons, respectively. On the other hand, the lowest values of sympodia on the main stem (12.93 and 13.96), were recorded from the half does of NPK mineral fertilizer in 2014 and 2015 seasons, respectively. This trend is expected since plant takes sufficient nutrients produced the first sympodium at a lower location than that in deprived ones. These results are in conformity with those obtained by (Moore 2006, Navarro et al 2008 and Kottegoda et al 2011), found that Functionalized nano-particles facilitate the enlargement of pore size or induction of new cell wall pore to enhance the uptake of nutrient which had significantly increase the vegetative growth and number of sympodia on the main stem.

\subsection{Boll weight in gram}

Data belonging to the boll weight of the investigated genotype under adopted treatments in the two experimental seasons were statistically significant in both seasons, and represented in (Table, 3). It is obvious that, the complex treatment between nano-fertilizer and bio-organic fertilizer with the ratio $50 \%: 50 \%$ for both of them exhibited the heaviest values of boll weight (2.66 and 2.76 gram) in both seasons, respectively followed by $100 \%$ nano-fertilizer then $100 \%$ NPK as a mineral fertilizer. In contrast, the treatment $(50 \%$ of recommended dose of mineral fertilizer recorded the lowest values (2.25 and 2.31 gram) in 2014 and 2015 season, respectively. 
Table 2. Plant height $(\mathrm{cm})$ and number of fruiting branches as affected by organic, mineral and nano- fertilization for Giza 94 during 2014 and 2015 seasons

\begin{tabular}{|l|c|c|c|c|c|c|}
\hline \multirow{2}{*}{ Treatments } & \multicolumn{3}{|c|}{ Plant height(cm) } & \multicolumn{2}{c|}{ Number of fruiting branches/plant } \\
\cline { 2 - 7 } & $\mathbf{2 0 1 4}$ & $\mathbf{2 0 1 5}$ & Mean & $\mathbf{2 0 1 4}$ & $\mathbf{2 0 1 5}$ & Mean \\
\hline 100\% NPK & 161.90 & 165.00 & 163.45 & 15.31 & 16.33 & 15.82 \\
$50 \%$ NPK & 139.10 & 143.00 & 141.05 & 12.93 & 13.96 & 13.45 \\
$50 \%$ Organic+50\% Nano & 163.21 & 166.24 & 164.73 & 15.71 & 16.74 & 16.23 \\
100\% Nano & 155.23 & 158.32 & 156.75 & 15.22 & 16.27 & 15.75 \\
$50 \%$ NPK+50\% Organic & 147.01 & 151.10 & 149.05 & 14.35 & 16.13 & 15.24 \\
$50 \%$ NPK+50\% NANO & 151.20 & 154.60 & 152.09 & 14.40 & 16.30 & 15.35 \\
100\% Organic & 143.18 & 147.20 & 145.19 & 14.15 & 14.60 & 14.38 \\
$50 \%$ Nano & 144.23 & 147,60 & 144.23 & 13.86 & 14.93 & 14.4 \\
\hline Mean & $\mathbf{1 5 0 . 6 3}$ & $\mathbf{1 5 5 . 0 6}$ & $\mathbf{1 5 2 . 1 7}$ & $\mathbf{1 4 . 4 9}$ & $\mathbf{1 5 . 6 5}$ & $\mathbf{1 5 . 0 7}$ \\
\hline L.S.D 5\% & $\mathbf{1 . 0 1}$ & $\mathbf{1 . 0 3}$ & & $\mathbf{3 . 0 3}$ & $\mathbf{2 . 8 9}$ & \\
\hline
\end{tabular}

This may be due to nano-materials more reactive, greater access than larger particles this lead to the great amount of the dry matter used to produce bolls. Which resulted from the great vegetative growth than the others treatments under study.

\subsection{Number of opened bolls / plant}

Data presented in (Table, 3 ) indicate that number of open bolls/ plant was influenced statistically by fertilizer treatments in 2014 and 2015 seasons.

The combination between bio-organic fertilizer and nano-fertilizer application surpassed the other treatments (21.58 and 21.63) in the two studied seasons respectively. Also, the treatment of $100 \%$ npk gave positive impact in Number of opened bolls / plant. On contrast, the treatment containing the half does of the NPK mineral fertilization gave the lowest values (10.46 and 10.50) in 2014 and 2015 seasons respectively.

This may be due to that both bio-organic and nano-fertilizers can boost the nutrient use efficiency through mechanisms, called slow release. They could exactly release their ingredient in responding to biological demands, adding to that nanofertilizers can improve crop productivity by enhancing germination, seedling growth, photosynthetic activity, nitrogen metabolism, both of carbohydrate synthesis and protein creation. These results are in harmony with those reported by (Arafa and Abd El-All 2013a, Arafa et al 2013b).

Table 3. Boll weight (gram) and no.of opened bolls as affected by organic, mineral and Nano- fertilization for Giza 94 during 2014 and 2015 seasons

\begin{tabular}{|l|c|c|c|c|c|c|}
\hline \multirow{2}{*}{ Characters } & \multicolumn{3}{|c|}{ Boll weight (gram) } & \multicolumn{2}{c|}{ No .of opened bolls / plant } \\
\cline { 2 - 7 } Treatments & $\mathbf{2 0 1 4}$ & $\mathbf{2 0 1 5}$ & Mean & $\mathbf{2 0 1 4}$ & $\mathbf{2 0 1 5}$ & Mean \\
\hline 100\% NPK & 2.46 & 2.60 & 2.58 & 18.95 & 20.12 & 19.54 \\
$50 \%$ NPK & 2.25 & 2.31 & 2.28 & 10.46 & 10.50 & 10.48 \\
$50 \%$ Organic+50\% Nano & 2.66 & 2.76 & 2.71 & 21.58 & 21.63 & 21.61 \\
$100 \%$ Nano & 2.47 & 2.70 & 2.53 & 18.78 & 18.80 & 18.79 \\
$50 \%$ NPK+50\% Organic & 2.44 & 2.45 & 2.45 & 18.26 & 19.00 & 18.63 \\
$50 \%$ NPK+50\% NANO & 2.41 & 2.50 & 2.46 & 15.30 & 19.00 & 17.15 \\
$100 \%$ Organic & 2.37 & 2.41 & 2.39 & 14.25 & 14.67 & 14.46 \\
$50 \%$ Nano & 2.31 & 2.40 & 2.36 & 11.33 & 11.50 & 11.42 \\
\hline Mean & $\mathbf{2 . 5 1}$ & $\mathbf{2 . 5 1}$ & $\mathbf{2 . 4 6}$ & $\mathbf{1 6 . 1 1}$ & $\mathbf{1 6 . 9 0}$ & $\mathbf{1 6 . 5 1}$ \\
\hline L.S.D 5\% & $\mathbf{0 . 1 4}$ & $\mathbf{0 . 0 4 2}$ & & $\mathbf{1 . 5 6}$ & $\mathbf{0 . 3 4}$ & \\
\hline
\end{tabular}




\subsection{Seed cotton yield $(k / f)$}

It is worthy to mention that, data belonging to seed cotton yield $(\mathrm{k} / \mathrm{f})$ were significant in both seasons, it's obvious from (Table, 4$)$ that all the seed cotton yield $(\mathrm{k} / \mathrm{f})$ reading express high crop yield regardless the treatment. This is true, since the current Egyptian genotypes usually associated with high crop yield except, the treatments of $50 \%$ mineral fertilizer, because the ratio of fertilizer not adequate for normal dry matter deposition. Thus the treatment including $50 \%$ bio-organic $+50 \%$ Nano gave the maximum seed cotton yield (14.20and 14.57) K/F in 2014 and 2015 growing seasons, respectively. Followed by $100 \%$ nano treatment in the first season only $(13.58 \mathrm{~K} / \mathrm{F})$ then the recommended dose of NPK. On the contrary, the transaction contains containing half recommended dose of mineral fertilizer NPK gave the lowest seed cotton yield (7.11and 7.37) K/F in 2014 and 2015 seasons, respectively.

\subsection{Lint cotton yield $(k / f)$}

Lint cotton yield (k/f) as affected by mineral, bio-organic, and nano-fertilizer and their combinations in 2014 and 2014 growing seasons are given in (Table, 4) data indicated that, the effects were significant in both studied seasons. The transaction containing both of the bio-organic and the nano-fertilizer with ratio $1: 1$ exhibited the highest lint cotton yield (5.95and $5.89 \mathrm{k} / \mathrm{f}$ ) in both seasons, respectively, as comparing to the recommended dose of mineral fertilizer; while, the lowest values (2.41and $2.57 \mathrm{k} / \mathrm{f}$ ) in 2014 and 2015 seasons, respectively were obtained from the half the recommended dose of mineral fertilizers. indicating the benefits and positive effect of bio-fertilizer is such able when the organic matter is found this may be due to that PGPR works in its best way when the $\mathrm{pH}$ of soil is acidic due to the decrease in soil $\mathrm{pH}$ due to tea compost active the soil bacteria and the ability of root uptake which reflected in plant metabolism (Arafa et al 2013b). As well as, the benefits of nano-fertilizer as inferred before.

\subsection{Lint percentage}

Data in (Table, 5) indicated that organic, mineral and nano-fertilization for Giza 94 genotype had significant effect on lint percentage. These effects were appeared during the two growing season; 2014, 2015 The results obtained indicated that the complex treatment contains half dose of both the nano-fertilizer and the bio-organic fertilizer gave the the greatest value of lint percentage (41.19and 41.53) \% in 2014 and 2015 seasons, respectively followed by $100 \%$ nano treatment (39.16 and 39.82) \% then the recommended dose of NPK. On the contrary, the transaction contains containing half recommended dose of mineral fertilizer NPK gave the lowest readings (34.35and 36.06) in 2014 and 2015 seasons, respectively. These results may explained that, bio-organic are able to augrament the plants by interfering the concentration of known phytohormone that those bacteria one of the most important way affect the growth and development by increase uptake of nutrients by plant. Also, nano-fertilizer increased uptake in plant cells by minimizing nutrient loss and increase the nutrient use efficiency. These results are in agreement with the results obtained by, (Morgan et al 2009 and Ghormade et al 2011).

\subsection{Seed index}

The influence of treatments applied during the study on this character is given in (Table, 5) Seed index values were affected significantly by the application of the studied fertilizer treatments. These results were fairly true in the two growing seasons; 2014 and 2015.

It is obvious that nano-fertilizer is boosting the seed index. The combination between the bioorganic fertilizer and nano-fertilizer in ratio $1: 1$ gave the largest values of seed index (12.75 and 12.76) gram in both seasons respectively, followed by $100 \%$ nano treatment. . On the other hand, the lowest values (10.36and 10.50) gram were obtained from $50 \%$ of the recommended does of the mineral fertilizer in 2014 and 2015 seasons, respectively. These results indicated that both nano and bio-organic fertilizer led to more accumulation of dry matter in cotton seeds, which reflected positively on seed index. 
Table 4. Seed cotton yield (k/f) and lint cotton yield $(\mathrm{k} / \mathrm{f})$ as affected by organic, mineral and nano-fertilization for Giza 94 during 2014 and 2015 seasons

\begin{tabular}{|l|c|c|c|c|c|c|}
\hline \multirow{2}{*}{ Treatments } & \multicolumn{3}{|c|}{ Seed cotton yield (k/f) } & \multicolumn{3}{c|}{ Lint cotton yield(k/f) } \\
\cline { 2 - 7 } & $\mathbf{2 0 1 4}$ & $\mathbf{2 0 1 5}$ & Mean & $\mathbf{2 0 1 4}$ & $\mathbf{2 0 1 5}$ & Mean \\
\hline 100\%NPK & 12.26 & 13.70 & 12.98 & 4.80 & 5.39 & 5.09 \\
50\%NPK & 7.11 & 7.37 & 7.24 & 2.41 & 2.57 & 2.49 \\
50\%Organic+50\%Nano & 14.20 & 14.57 & 14.39 & 5.95 & 5.89 & 5.92 \\
100\%Nano & 13.58 & 12.17 & 12.88 & 4.64 & 4.65 & 4.64 \\
$50 \%$ NPK+50\%Organic & 12.23 & 12.49 & 12.36 & 4.64 & 4.86 & 4.75 \\
50\%NPK+50\%NANO & 12.04 & 12.50 & 12.27 & 4.80 & 4.88 & 4.84 \\
100\%Organic & 11.86 & 12.06 & 11.96 & 4.18 & 4.53 & 4.36 \\
50\%Nano & 7.21 & 7.76 & 7.49 & 2.59 & 3.19 & 2.89 \\
\hline Mean & $\mathbf{1 1 . 3 2}$ & $\mathbf{1 1 . 5 4}$ & $\mathbf{1 1 . 4 3}$ & $\mathbf{4 . 2 5}$ & $\mathbf{4 . 4 9}$ & $\mathbf{4 . 3 7}$ \\
\hline L.S.D 5\% & $\mathbf{0 . 2 4}$ & $\mathbf{0 . 5 0}$ & & $\mathbf{0 . 3 4}$ & $\mathbf{0 . 3 7}$ & \\
\hline
\end{tabular}

Table 5. Lint percentage and seed index as affected by organic, mineral and nano- fertilization for Giza 94 during 2014 and 2015 seasons

\begin{tabular}{|l|c|c|c|c|c|c|}
\hline \multirow{2}{*}{ Characters } & \multicolumn{3}{|c|}{ Lint percentage \% } & \multicolumn{3}{c|}{ Seed index (gram) } \\
\cline { 2 - 7 } Treatments & $\mathbf{2 0 1 4}$ & $\mathbf{2 0 1 5}$ & Mean & $\mathbf{2 0 1 4}$ & $\mathbf{2 0 1 5}$ & Mean \\
\hline 100\% NPK & 38.45 & 39.78 & 37.12 & 11.89 & 12.52 & 11.25 \\
50\% NPK & 34.35 & 36.06 & 32.64 & 10.36 & 10.50 & 10.21 \\
50\% Organic+50\% Nano & 41.19 & 41.53 & 40.84 & 12.75 & 12.76 & 12.74 \\
100\% Nano & 39.16 & 39.82 & 38.54 & 12.44 & 12.55 & 12.33 \\
50\% NPK+ 50\% Organic & 38.58 & 39.80 & 37.36 & 11.32 & 11.42 & 11.21 \\
50\% NPK+50\% NANO & 38.20 & 38.70 & 37.70 & 11.83 & 12.51 & 11.15 \\
100\% Organic & 36.47 & 38.25 & 34.68 & 10.96 & 11.10 & 10.81 \\
50\% Nano & 34.95 & 36.20 & 33.70 & 10.70 & 10.83 & 10.56 \\
\hline Mean & $\mathbf{3 7 . 6 7}$ & $\mathbf{3 8 . 7 7}$ & $\mathbf{3 6 . 5 7}$ & $\mathbf{1 1 . 5 3}$ & $\mathbf{1 1 . 7 7}$ & $\mathbf{1 1 . 2 8}$ \\
\hline L.S.D 5\% & $\mathbf{1 . 1 2}$ & $\mathbf{1 . 3 0}$ & & $\mathbf{0 . 3 4}$ & $\mathbf{0 . 2 2}$ & \\
\hline
\end{tabular}

\section{Fiber physical properties}

\subsection{Fiber Upper Half Mean (mm)}

Data in (Table, 6) represents the significant effect of mineral, bio-organic, nano-fertilization and their combination on UHM reading of Giza 94 cultivar the in both the studied seasons

It is evident that UHM reading ranged from $33.83 \mathrm{~mm}$ to $31.52 \mathrm{~mm}$ in 2014 season and from $33.93 \mathrm{~mm}$ to $31.66 \mathrm{~mm}$ in 2015 season indicating the positive effect of the combination between bio and nano-fertilizers in improving fiber length by $0.51 \mathrm{~mm}$ and $0.53 \mathrm{~mm}$ in 2014 and 2015 growing seasons, respectively than the recommended does of NPK mineral fertilizer. These results are in line with Arafa et al (2013), Khalil and Arafa (2013).

\subsection{Fiber uniformity index (UI)}

The results in (Table, 6 ) represent the effect of the considered genotype under adopted treatments in the two seasons on fiber uniformity index. It could be recognized that the effects of the fertilizer and their combinations treatments were significant in both seasons. The combination between the bio-organic fertilizer and nano-fertilizer in ratio 1:1 gave the largest values of fiber uniformity index 
(89.90 and 89.95) in 2014 and 2015 seasons, respectively. On the other hand, the lowest values were obtained from $50 \%$ of the recommended dose of the mineral fertilizer in 2014 and 2015 seasons, respectively. These results indicated that both nano and bio-organic fertilizer led to more accumulation of dry matter in cotton fibers, and increase the cellulose deposition in the secondary wall which forms the body of the fiber. This led to more strength and less rupture in fiber which reflected positively on uniformity index.

\subsection{Fiber strength (g/tex)}

Fiber strength as affected by mineral, bioorganic, and nano-fertilizer and their combinations in 2014 and 2014 growing seasons are given in (Table, 7) data indicated that, the effects were significant in both studied seasons. The transaction containing both of the bio-organic and the nano-fertilizer with ratio $1: 1$ exhibited the strongest fibers (45.81 and $45.90 \mathrm{~g} / \mathrm{tex}$ ) in both seasons, respectively, as comparing to the recommended dose of mineral fertilizer; while, the weakest fiber strength values (35.32 and $35.99 \mathrm{~g} / \mathrm{tex}$ ) in 2014 and 2015 seasons, respectively were obtained from the half the recommended does of mineral ferilizers. indicating the benefits and positive effect of bio-fertilizer is such able when the organic matter is found this may be due to that PGPR works in its best way when the $\mathrm{pH}$ of soil is acidic due to the decrease in soil $\mathrm{pH}$ due to tea compost active the soil bacteria and the ability of root uptake which reflected in plant metabolism Arafa et al (2013). As well as, the benefits of nano-fertilizer as inferred before.

\subsection{The percentage of fiber elongation}

The influence of treatments applied during the study on this character was given in (Table, 7). There were no significant differences between the means of the fiber elongation \% due to the treatments applied during the study in 2014 season; While, it significant in 2015 season. It's worthy to mention that, the percentage of fiber elongation had no constant trend due to fertilizer transactions applied on the adopted genotype during' 2015 season. But, it seems to be that nano-fertilizer is boosting the elongation percent.

\subsection{Micronaire value}

Data presented in (Table, 8 ) revealed that $\mathrm{mi}-$ cronaire values were affected significantly by the application of the studied fertilizer treatments. These results were fairly true in two growing seasons; 2014and 2015. It could be arranged in descending order with regard to micronaire values as follows: $50 \%$ bio-organic $+50 \%$ Nano (4.41 and 4.43), $100 \%$ Nano (4.22 and 4.36) ,100\% NPK (4.21 and 4.30) then the rest treatments in 2014 and 2015 growing seasons, respectively.

The inferred result indicated that, micronaire values tended to increase by applying nanofertilizer this could be attributed the fact that micronaire values incorporates both intrinsic fineness and maturity, when samples belongs to the same genotype the different micronaire values express difference in maturity because fineness is limited by the genotype.

So, the increment in micronaire value may be ascribed to the increasing in fiber maturity as a direct impact of both of the bio-organic and nanofertilizer in plant metabolism and the other vital activities. Similar trend was observed by Moore (2006), Navarro et al (2008), Kottegoda et al (2011), Arafa et al (2013b).

\subsection{Fiber maturity ratio}

It is worthy to mention that, data belonging to fiber maturity ratio were significant in both seasons, it's obvious from (Table, 8) that all the maturity reading express high maturity ratio regardless the treatment .This true, since the Egyptian genotypes usually associated with high maturity ratio except, the treatments of $50 \%$ mineral fertilizer or $50 \%$ nano-fertilizer, because the ratio of fertilizer not adequate for normal cellulose deposition as it well known that; fiber growth is known to occur in two fairly distinct stages, the first growth stage corresponds to the fiber elongation and the second growth stage corresponds to the secondary wall formation. The period of elongation seems to be determined by genotype; however second growth stage is influenced by the growing conditions such as, nutrients uptake. This explained the increment in fiber maturity in the treatment including 50\%bio-organic+50\%Nano (0.99 and 1.00$)$ in 2014 and 2015 growing seasons, respectively. 
Table 6. Upper half mean (U.H.M) and fiber uniformity index (U.I) as affected by organic, mineral and nano-fertilization for Giza 94 during 2014 and 2015 seasons

\begin{tabular}{|l|c|c|c|c|c|c|}
\hline \multirow{2}{*}{ Treatments } & \multicolumn{3}{|c|}{ U.H.M(mm) } & \multicolumn{3}{c|}{ U.I \% } \\
\cline { 2 - 7 } & $\mathbf{2 0 1 4}$ & $\mathbf{2 0 1 5}$ & Mean & $\mathbf{2 0 1 4}$ & $\mathbf{2 0 1 5}$ & Mean \\
100\% NPK & 33.32 & 33.40 & 33.36 & 88.32 & 89.33 & 88.83 \\
$50 \%$ NPK & 31.52 & 31.66 & 31.59 & 81.69 & 81.72 & 81.71 \\
$50 \%$ Organic+50\% Nano & 33.83 & 33.93 & 33.88 & 89.90 & 89.95 & 89.92 \\
$100 \%$ Nano & 33.40 & 33.53 & 33.46 & 89.31 & 86.37 & 87.84 \\
$50 \%$ NPK+50\% Organic & 33.35 & 33.46 & 33.41 & 88.11 & 88.14 & 88.13 \\
$50 \%$ NPK+50\% NANO & 33.46 & 33.52 & 33.49 & 86.35 & 88.35 & 87.35 \\
100\% Organic & 33.30 & 33.37 & 33.34 & 85.70 & 85.72 & 85.71 \\
$50 \%$ Nano & 32.00 & 32.26 & 32.13 & 82.62 & 82.64 & 82.63 \\
\hline Mean & $\mathbf{3 3 . 0 2}$ & $\mathbf{3 3 . 1 4}$ & $\mathbf{3 3 . 0 8}$ & $\mathbf{8 6 . 5 0}$ & $\mathbf{8 6 . 5 5}$ & $\mathbf{8 6 . 5 2}$ \\
\hline L.S.D 5\% & $\mathbf{0 . 2 5}$ & $\mathbf{0 . 5 6}$ & & $\mathbf{0 . 2 4}$ & $\mathbf{0 . 4 2}$ & \\
\hline
\end{tabular}

Table 7. Fiber strength ( $g /$ tex) and fiber elongation \% as affected by organic, mineral and nano-fertilization for Giza 94 during 2014 and 2015 seasons

\begin{tabular}{|l|c|c|c|c|c|c|}
\hline \multirow{2}{*}{ Treatments } & \multicolumn{3}{|c|}{ fiber strength(g/tex) } & \multicolumn{3}{c|}{ fiber elongation \% } \\
\cline { 2 - 7 } & $\mathbf{2 0 1 4}$ & $\mathbf{2 0 1 5}$ & Mean & $\mathbf{2 0 1 4}$ & $\mathbf{2 0 1 5}$ & Mean \\
\hline 100\%NPK & 42.77 & 45.35 & 44.06 & 7.13 & 7.19 & 7.14 \\
50\%NPK & 35.32 & 35.99 & 35.65 & 7.10 & 7.11 & 7.11 \\
50\%Organic+50\%Nano & 45.81 & 45.90 & 45.86 & 7.19 & 7.21 & 7.23 \\
100\%Nano & 40.20 & 45.31 & 42.76 & 7.14 & 9.21 & 7.14 \\
50\% NPK+50\%Organic & 42.32 & 42.37 & 42.35 & 7.13 & 7.15 & 7.14 \\
50\%NPK+50\%NANO & 40.17 & 42.79 & 41.48 & 7.13 & 7.19 & 7.14 \\
100\%Organic & 38.94 & 38.95 & 38.95 & 7.12 & 7.14 & 7.13 \\
50\%Nano & 36.02 & 37.25 & 36.64 & 7.11 & 7.21 & 7.12 \\
\hline Mean & $\mathbf{4 0 . 1 9}$ & $\mathbf{4 1 . 7 3}$ & $\mathbf{4 0 . 9 7}$ & $\mathbf{7 . 1 3}$ & $\mathbf{7 . 1 7}$ & $\mathbf{7 . 1 5}$ \\
\hline L.S.D 5\% & $\mathbf{1 . 0 1}$ & $\mathbf{1 . 5 6}$ & & $\mathbf{N . s}$ & $\mathbf{0 . 0 2}$ & \\
\hline
\end{tabular}


Table 8. Micronire reading and maturity ratio as affected by organic , mineral and nanofertilization for Giza 94 during 2014 and 2015 seasons

\begin{tabular}{|l|c|c|c|c|c|c|}
\hline \multirow{2}{*}{ Treatments } & \multicolumn{3}{|c|}{ Micronire reading } & \multicolumn{3}{c|}{ Maturity ratio } \\
\cline { 2 - 7 } & $\mathbf{2 0 1 4}$ & $\mathbf{2 0 1 5}$ & Mean & $\mathbf{2 0 1 4}$ & $\mathbf{2 0 1 5}$ & Mean \\
\hline 100\% NPK & 4.21 & 4.30 & 4.25 & 0.95 & 0.99 & 0.97 \\
$50 \%$ NPK & 3.38 & 3.47 & 3.42 & 0.80 & 0.80 & 0.80 \\
50\% Organic+50\% Nano & 4.41 & 4.43 & 4.42 & 0.99 & 1.00 & 0.99 \\
100\% Nano & 4.22 & 4.36 & 4.29 & 0.98 & 0.95 & 0.96 \\
$50 \%$ NPK+50\% Organic & 3.89 & 4.91 & 4.40 & 0.94 & 0.96 & 0.95 \\
$50 \%$ NPK+50\% NANO & 4.11 & 4.30 & 4.20 & 0.94 & 0.96 & 0.95 \\
$100 \%$ Organic & 4.10 & 4.23 & 4.16 & 0.93 & 0.93 & 0.93 \\
$50 \%$ Nano & 3.61 & 3.63 & 3.62 & 0.83 & 0.84 & 0.83 \\
\hline Mean & $\mathbf{3 . 9 9}$ & $\mathbf{4 . 2 0}$ & $\mathbf{4 . 0 9}$ & $\mathbf{0 . 9 2}$ & $\mathbf{0 . 9 3}$ & $\mathbf{0 . 9 2}$ \\
\hline L.S.D 5\% & $\mathbf{0 . 7 1}$ & $\mathbf{0 . 0 7}$ & & $\mathbf{0 . 0 1}$ & $\mathbf{0 . 0 2}$ & \\
\hline
\end{tabular}

\section{REFERENCES}

American Stander for Testing Materials (ASTM), -1986.USA http://www.astm.org/

Arafa, Abeer, S. and Abd El-All, A.M. 2013a. Evaluation of the technological properties of bio-organic colored cotton J. of Agron., 12(2), 78-85.

Arafa, Abeer.S. , Khalil, H.M. and Gebaly, Sana, G. 2013b. Impact of eco-friendly fertilizers and rice straw on cotton yield and fiber physical properties. Inter. Sci. and Inve., J. 2(1), 1-12.

Corradini, M.R., Moura, L.de. and Mattoso, H.C. 2010. A preliminary study of the incorparation of NPK fertilizer into chitosan nanoparticles express Polymer Letters. 4(8), 509-515.

DeRosa, M.C., Monreal, C., Schnitzer, M., Walsh, R. and Sultan, Y. 2010. Nanotechnology in fertilizers. Nat Nanotechno. 5(2), 58-91.

Dhale, D.A., Chatte, S.N. and Jadhav, V. T. 2011. Response of bioinoculents on growth, yield and fiber quality of cotton under irrigation. Agric. and Biology J. of North America. Sci., 1(8), 145-152.

Eichert, T., Kurtz, A., Steiner, U. and Goldbach, H.E. 2008. Size exclusion limits and lateral heterogeneity of the stomatal foliar uptake pathway for aqueous solutes and watersuspended nano particles. Physiol. Plant 8(1), 134-151.
Ghormade, V., Deshpande, M.V. and Paknikar, K.M. 2011. Perspectives for nanobiotechnology enabled protection and nutrition of plants. J. Biotechnol Adv., 29(6), 792-803.

Jackson, M.L. 1976. "Soil chemical analysis". Prentice- Hall, Inc. Engle Wood Cliffs, N.J., 1958, 498 S. DM, pp. 39-40.

Khalil, H.M. and Abeer, S. Arafa 2013. Influence rice straw and bio organic fertilization on cotton fiber quality under saline soils. J. of Agron. 12(2), 86-92.

Kottegoda, N., Munaweera, I., Madusanka, A.N. and Karunaratne, V. 2011. Compositions for sustained. Release of agric macronutrients and process the. Re . of . W2O 11151724.

Moore, M. 2006. Do nanoparticles present Eco toxicological risks for the health of the aquatic environment Environ Int., 32(8), 967-976.

Morgan, K.T., Cushman, K.E. and Sato, S., 2009. Release mechanisms for slow- and controlled-release fertilizers and strategies for their use in vegetable, production. Hort Technol 19(1), 10-12.

Navarro, E., Baun, A., Behra, R., Hartmann, N.B., Filser, J., Miao, A.J., Quigg, A., Santschi, P.H. and Sigg, L. 2008. Environmental behavior and Eco toxicity of engineered nanoparticles to algae, plants, and fungi. Ecotoxicology 17(5), 372-386. 
Rico, C.M., Majumdar, S., Duarte-Gardea, M., Peralta-Videa, J.R. and Gardea-Torresdey, J.L. 2011. Interaction of nanoparticles with edible plants and their possible implications in the food chain. J. Agric. Food Chem., 59(8), 3485-3498.

Sasson, Y., Levy-Ruso, G., Toledano, O. and Ishaaya, I. 2007. Nano suspensions: emerging novel agrochemical formulations. In: Ishaaya I, Horowitz AR, Nauen R (eds.). Insecticides design using advanced technologies. Springer, Berlin, 6, 1-39.
Sendecore, G.W. and Cochran, W.G. 1981. Statistical Methods. $7^{\text {th }}$ ed. lowa State Univ., Ames, IA.

Shivalingaiah, M. 2007. Effect of nutrient management and plant protection practices in organic cotton production (Gossypium spp.) M.Sc. Thesis, Univ., of Agric. Sci., Dharwad, India, 90 p.

http://krishiosh.egranth.ac.in/bitstream/1/80649/ $\underline{1 / \operatorname{th} 9941}$ 